Irina $\mathbf{P}$. Devetyarova $^{1}$

Oksana S. Agalakova Larisa S. Cheglakova Yulia A. Kolesova

Article info: Received 17.10.2019 Accepted 05.02.2020

UDC -659.1

DOI - 10.24874/IJQR14.02-12

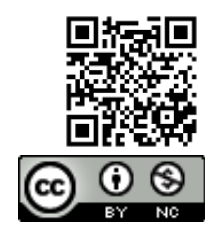

\section{INSTITUTIONALIZATION OF SUCCESSFUL MARKETING PRACTICES OF DIGITAL UNIVERSITIES BASED ON QUALITY MANAGEMENT IN MODERN RUSSIA}

Abstract: The purpose of the paper is to substantiate the important role of quality management of provided educational services for success of marketing practices of a digital university and to develop recommendations for institutionalization of successful marketing practices of digital universities based on quality management in modern Russia. The authors use the case method and the methods of logical, comparative, trend, and regression analysis. The authors perform a critical analysis of marketing practices of digital universities in modern Russia and compare the consumer preferences as to the choice between the traditional and digital educational services in case of absence and in case of presence of experience of digital training. Also, growth of the indicators of quality of educational services, provided by digital universities, and growth of the indicators of efficiency of their marketing practices are compared. The research objects are top 10 digital universities of Russia (according to the 2019 rating). As a result, it is substantiated that results of implementation of marketing practices of digital universities in modern Russia depend on quality management of provided educational services. A restraining factor on the path of development of digital universities in modern Russia is their insufficient attention to the issues of quality management, which reduces the efficiency of marketing activities and causes their low competitiveness as suppliers of educational services, objects of investing, and employers. The offered recommendations will allow raising the quality and marketing activity of digital universities in Russia and ensuring institutionalization of their successful marketing practices, thus stimulating the increase of efficiency of marketing activities.

Keywords: Institutionalization; Successful marketing practices; Digital universities; Modern Russia; Quality management

\section{Introduction}

Modern Russia has been conducting digital modernization of economy for a long time now. Recently, the country started its final stage - transition to Industry 4.0. The first

1 Corresponding author: Irina P. Devetyarova

Email: ip_devetyarova@vyatsu.ru strategy of building the information digital) society in Russia was adopted in 2008 and was supposed to have an anti-crisis effect on the Russian economy. 2017 saw the adoption of the federal program of formation of the digital economy, based on breakthrough technologies of Industry 4.0 (AI, the Internet 
of Things, etc.). One of the basic directions of this program was "personnel and education" for the digital economy (Digital economy of the Russian Federation 2024, 2019).

Implementing this direction based on traditional (pre-digital) universities, which use traditional technologies in the educational process (personal interaction between lecturers and students, usage of paper materials), which apply traditional (intramural, extramural, etc.) forms of provision of educational services and implement educational programs that are not aimed at development of digital competencies with students, is very slow or is impossible. That's why digital universities are created for implementing this direction in Russia. However, at present (2019), their share in the Russian market of educational services is very small, so the data on them are not given in statistics reports.

One of the most perspective mechanisms of development of digital universities, as well as of the market of educational services in Russia on the whole, by the state and by universities is marketing practices. A logical substantiation of increase of marketing activity of digital universities is, firstly, establishing and supporting sustainable direct communication between digital universities and interested parties. This is necessary for informing the interesting parties on advantages of digital universities and increase of society's loyalty to their activities.

Due to insufficient marketing support for the activities of digital universities in the modern Russian society there appeared a false idea of them as of "shadow" (which do not fully observe the federal state educational standards) participants of the market of higher educational services. Due to absence of guarantees of provision of digital universities' educational services of certain quality, their graduates are not in high demand among employers, which reduces the value of the issued diplomas on higher education and reduces demand for their services.
Marketing of digital universities is to raise the awareness of applicants, students, employers, and other interested parties on organization of the educational process and to persuade society about the guarantee of high quality of the provided educational services. Marketing could take two forms. 1st form: branding of digital universities, which envisages their advertising and PR with emphasis on competitive advantages as compared to traditional (pre-digital) universities - lower cost of studies, possibility to combine studying and working, etc. 2nd form: informing the interested parties on experience of obtaining higher education in digital universities, employment, and career building with emphasis on the absence of differences between quality of traditional and digital studies.

Secondly, marketing is also to ensure feedback between digital universities and interested parties. Collection of information on the situation in the market of higher educational services and the tendencies of its change under the influence of the change of consumer preferences will allow digital universities to show flexibility, adapting to the new economic conditions and supporting their competitiveness at a high level. Unlike traditional (pre-digital) universities, which competitiveness is based on stability, digital universities have to develop in order to provide advantages for consumers of their services (high convenience of training, variative character of educational programs, etc.) with quality of education that is similar to traditional training.

In both cases (direct and reverse marketing), an important factor of efficiency of marketing activities of digital universities is quality of the provided educational services. Based on this, we offer a hypothesis that the results of implementation of marketing practices of digital universities in modern Russia depend on management of quality of the provided educational services (H1). We also suppose that a serious restraining factor on the path of development of digital universities in modern 
Russia is their insufficient attention to the issues of quality management, which reduces the efficiency of marketing activities and causes their low competitiveness as suppliers of educational services, objects of investing, and employers $(\mathrm{H} 2)$.

The purpose of the research is to substantiate the important role of managing the quality of provided educational services for success of marketing practices of a digital university and to develop recommendations for institutionalization of successful marketing practices of digital universities based on quality management in modern Russia.

\section{Literature review}

Digital university is a new notion for the modern economic science. As a result of the content analysis of the existing studies and publications on the topic of digital university, we determined the following specific features:

usage of the leading digital technologies in the educational process: e.g., application of multimedia projectors during lectures, application of technologies of virtual and alternate reality during practical studies, and interaction between lecturers and students within the training process with the help of digital technologies (Internet, e-mail): noted in (Akşit, 2018) and (Kazimirov, 2018);

application of the digital form of provision of educational services: remote training which envisages translation of prepared sample digital materials (e.g., video lectures) and interactive interaction of lecturers and students, as a result of which digital diplomas are issued: noted in works (Popkova, 2019) and (Saud et al. 2018);

implementing educational programs on training of digital personnel: these programs are aimed at developing digital competencies (possession of the leading information and communication technologies that are applied in a corresponding profession) with students: substantiate in the work (Sozinova, 2019).
For a university to be considered digital one, all three above features should be present, for they determine the peculiarities of digital universities as compared to traditional (predigital) universities.

Marketing practices of modern universities are discussed in a lot of works. GregorySmith et al. (2018) study the influence of ecological and social marketing on university's employees. Peruta and Shields (2018) suggest conducting university marketing in social networks (shown by the example of Facebook). Sekerin et al. (2018) substantiate the expedience of applying the methods of interactive marketing for increasing the quality of university educational services.

The problem of measuring the quality of educational services, provided by digital universities, is studied indirectly in a small number of specialized works of modern experts. Schuettler et al. (2019) offer a perspective technology of measuring the quality of remote education with the help of special sensors. Hu (2013) studies the perspectives of increasing the quality of remote education by applying an alternativeoriented tutoring (author's term).

Blieck et al. (2019) thinks that it is necessary to search for a consensus of interested parties as to factors of success and indicators of quality of online and mixed training in higher education. Mishra \& Mishra (2018) provide recommendations for increasing the quality in the system of online education with the usage of the methods of intellectual analysis of data. Du et al. (2018) develop a methodology of studying and building a model of assessment of quality of services, which is based on treatment of a customer in the sphere of online education. Ahern (2018) think that network education in the online regime should develop together with demand for high-quality and flexible education.

Esfijani (2018) notes that measuring quality in online education is peculiar for high complexity. Stracke \& Tan (2018) offer to use models (analyzing competitiveness) for 
measuring the quality of open online education. Osman et al. (2018) study the intermediary role of the university's image in formation of quality of digital education with the help of modeling and complication of the system of structural equations. Pedro et al. (2018) write that training methods influence the quality of digital education. Sharok (2018) points out the influence of sociopsychological factors on satisfaction with digital education. Vučijak et al. (2018) come to the conclusion that quality of digital education is flexible and depends on geographical (socio-cultural) factors.

Popkova (2019) points out that in the conditions of the knowledge economy and establishment of Industry 4.0 the significance and need for digital education grow. Popkova et al. (2017a), Popkova et al. (2017b) and Popkova et al. (2017c) offer methods for measuring the quality of media education. Popkova \& Sergi (2019) note that quality of digital education depends on the evaluation subject. Sibirskaya et al. (2019) oppose remote education to traditional education and deem it necessary to use different methods for evaluating their quality. Petrenko et al. (2018) suggest using the methodology of assessment of quality of services in the post-industrial economy as to digital education.

The performed literature overview showed that despite the fact that issues of marketing activities of modern universities are studied sufficiently in the existing scientific economic literature, marketing of digital universities, as a specific category of universities, which deserves more attention and research, is poorly studied. The role of quality for achieving the results of marketing activities of digital universities is not determined by the modern economic science and requires specification. The determined gaps and the necessity to fill them are the led to the goals of this research.

\section{Methodology}

For verification of hypothesis $\mathrm{H} 2$ the authors use the case method. The authors perform critical (logical) analysis of marketing practices of digital universities in modern Russia. The authors also use the method of comparative analysis for comparing consumer preferences regarding the choice between traditional (intramural) and digital (remote) educational services in case of absence or presence of experience of digital (remote) training. The confirmation of hypothesis $\mathrm{H} 2$ is a large share of consumers who prefer digital (remote) services, in case of experience of obtaining them, as compared to consumers without the corresponding experience.

Hypothesis $\mathrm{H} 1$ is verified by comparing the growth of the indicators of quality of educational services, provided by digital universities, to growth of the indicators of efficiency of their marketing practices. Growth in 2018, as compared to 2017, is determined with the help of horizontal analysis (ratio of 2018 data to 2017 data is calculated). The connection between the indicators of quality and the indicators of efficiency of marketing practices is studied with the help of the method of regression analysis: coefficients $b$ in the models of paired linear regression of the type $y=a+b * x$ are calculated, which show the change of $y$ due to increase of $\mathrm{x}$ by 1 ; coefficients of determination (R2) are calculated, which characterize correlation (share of change of $y$, which could be explained by the change of $\mathrm{x}$ ) of the indicators.

The research objects are top 10 digital universities of Russia (according to the 2019 rating, prepared by the expert and analytical agency Vuzopedia)(Vuzopedia, 2019):

1) Moscow Region State University (MRSU);

2) Moscow Finance and Law University (MFLU); 
3) Russian State University for the Humanities (Domodedovo, Moscow Oblast) (RSUH);

4) Moscow State University of Civil Engineering (NR MSUCE);

5) Financial University under the Government of the Russian Federation (FU);

6) National University of Science and Technology MISiS (MISiS);

7) Moscow City Pedagogical University (MCPU);

8) Moscow State University of Civil Engineering (MSUCE);

9) Russian University of Transport (RUT);

10) Moscow State University of Geodesy and Cartography (MSUGC).

Abbreviations (generally accepted) of universities' names are given in parentheses. As could be seen, all leading digital universities of Russia are concentrated in Moscow Oblast (primarily in Moscow). This is due to the fact that provision of educational services in the digital (remote) form is a pilot (risky) project, which is implemented by the most competitive (and thus sustainable) and developed universities of Russia - so they are concentrated in the capital.

The source of statistical data on the activities of digital universities are information and analytical materials on the results of monitoring of effectiveness of the activities of educational organizations of higher education as a result of 2017 and 2018. The indicator of quality of educational services, which are provided by digital universities, are the following indices, calculated by the Ministry of Education and Science of the Russian Federation (2019):

- E1: Educational activities, points;

- E2: Research activities, RUB thousand;

- $\quad$ E3: International activities, \%;

- E4: Financial and economic activities, RUB thousand;

- $\quad$ E5: Wages of academic staff, $\%$.
The indicators of efficiency of implementing the marketing practices of digital universities are as follows (provided additionally in the materials of the Monitoring and absent in the above indices):

- University's revenues from all sources, RUB thousand.: characterize the volume of sales;

- Share of full-time academic staff in the total number of academic staff, $\%$ : characterizes the attraction of personnel;

- Total number of students, people: characterizes demand for provided educational services;

- Share of university's revenues from non-budget sources, \%: characterizes attraction of investments;

- Share of foreign students, \%: characterizes provision of international educational services by the university.

The proof of hypothesis $\mathrm{H}_{1}$ is direct connection (positive value of direct average of all estimate coefficients b) of the indicators of quality of educational services, provided by digital universities, and efficiency of their marketing practices.

\section{Results}

\subsection{Overview and critical analysis of implementation of marketing practices of digital universities in modern Russia from the positions of quality management}

As a result of empirical study of the modern Russian practice of creation and functioning of digital universities, we determined that, firstly, most of modern Russian universities use separate digital technologies in the educational process, of which the most popular is multimedia projector. However, breakthrough technologies of Industry 4.0 (e.g., technologies of virtual and alternate reality) are not used. 
Secondly, educational programs for training of digital personnel are a new initiative in modern Russia. This initiative is to be implemented - as an addition to the main traditional scientific and educational activities - by flagship universities (formed in 2016-2017), which receive target financing for training of digital personnel (Ministry of Education and Science of the Russian Federation, 2019a). University "National Technological Initiative" 20.35 was created in 2018 for training of digital personnel.

Thirdly, application of the digital form of provision of educational services is the most vivid specific feature of the Russian digital universities. The option of remote education is provided by the growing number of Russian universities - though most of them are not digital universities. Private and nonprofit universities consider remote education as a possibility of expansion of sales markets and gaining advantages from "scale effect", while target application of the possibilities of remote education for training of digital personnel is not very popular in modern Russia.

For studying the results of implementation of marketing practices by digital universities in modern Russia, let us use the materials of a sociological survey "Remote education in Russia", conducted by the Fund of public opinion research (2019) in 2018 (Figure 1-3).

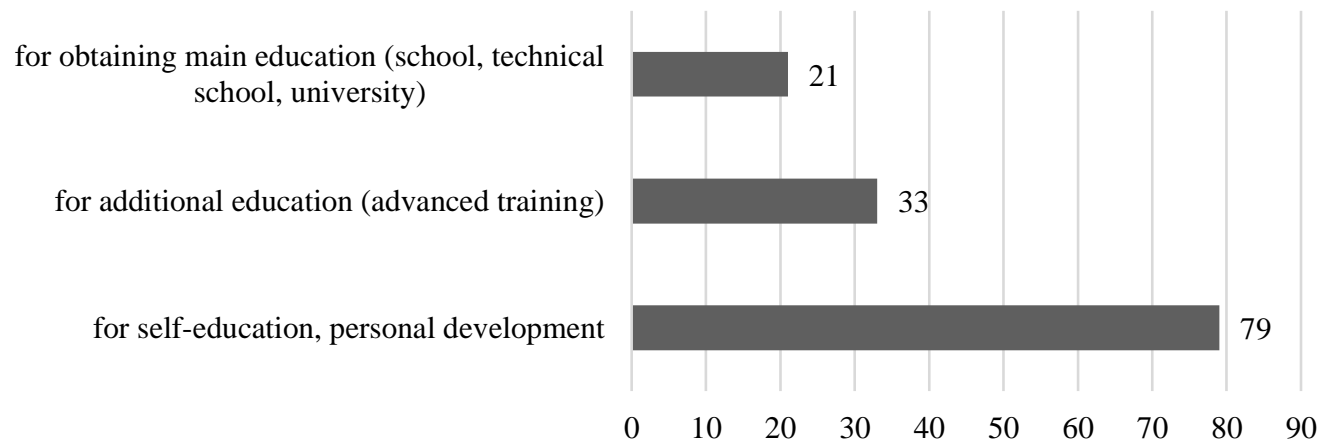

Figure 1. Experience of remote education in Russia in view of types of education Source: compiled by the authors based on (Fund of public opinion research (2019)

As shown in Figure 1, 21\% of Russians have experience of remote education (Fund of public opinion research (2019). As shown in Figure 1, 21\% of the respondents have experience of obtaining main education in the remote form; $33 \%$ have experience of additional education; 79\% - experience of self-education and personal development. Therefore, demonstration practices and advertising events are not conducted by the modern Russian digital universities. Experience of remote education is acquired by consumers independently or when seeking the remote educational services from a university -i.e., by the initiative of consumer, not by the initiative of universities in the process of their marketing activities.

As shown in Figure 2, respondents without experience of remote education distrust it only $22 \%$ prefer remote education and $4 \%$ prefer combination of remote and intramural education.

Figure 3 shows that respondents with experience of remote education show higher readiness to obtain education remotely. 33\% of them prefer remote education and 105 prefer combination of remote and intramural education. 


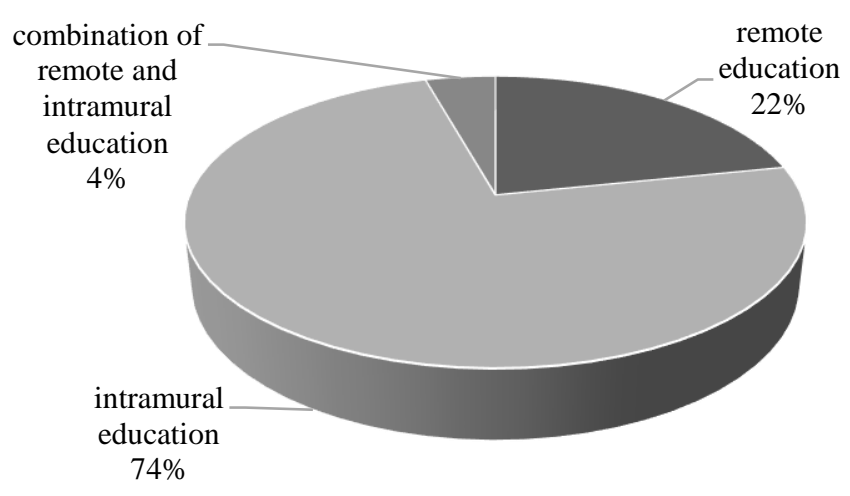

Figure 2. Respondents' preferences as to the forms of obtaining education (respondents do not have experience of remote education)

Source: compiled by the authors based on (Fund of public opinion research (2019)

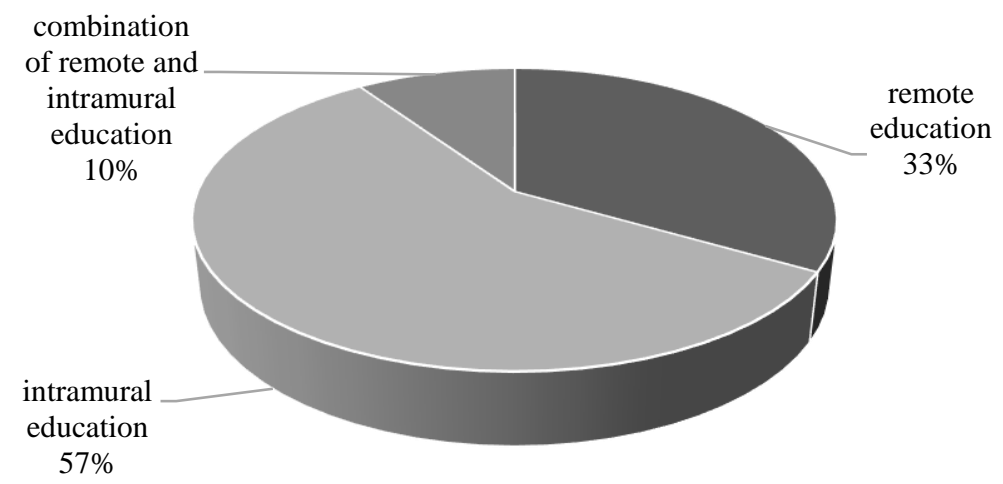

Figure 3. Preferences of the forms of education by respondents with experience of remote education

Source: compiled by the authors based on (Fund of public opinion research (2019)

Therefore, one of the most important directions of marketing activities of digital universities - promotion of remote education - is not implemented in modern Russia. Without full-scale marketing support, remote education has low demand among Russian consumers of educational services. As the share of consumers that prefer digital (remote) services, in case of presence of experience with them (33\%), is higher than among consumers without the corresponding experience (22\%), hypothesis $\mathrm{H}_{2}$ is deemed proved.

As the presence of experience of remote education is an important factor of preferring the remote form of obtaining educational services, there are wide perspectives and high need for implementing the marketing practices by modern Russian digital universities, as well as their institutionalization - establishment and translation of experience and further sustainable mass application for maximization of the achieved positive effect. 
Insufficient attention is paid to quality management during implementation of marketing practices by digital universities in Russia, which reduces the efficiency of these practices. Experience of digital training allows consumers to make sure of high quality of educational services, which are provided by digital universities. However, lack of confidence in high quality of services of digital universities in society reduces competitiveness of their graduates in the labor market, hindering their employment and career building.

That's why even in case of presence of experience of digital training, most of consumers $(57 \%)$ prefer traditional (intramural) training. Therefore, during implementation of marketing practices, digital universities have to ensure high quality of the provided educational services and to promote their services with emphasis on their high quality (quality has to be an object of promotion, not just an accompanying factor).

\subsection{Analysis of influence of quality management on efficiency of marketing practices of digital universities in modern Russia}

The initial statistical data for analysis of the influence of quality management on efficiency of marketing practices of digital universities in modern Russia in 2017-2018 are shown in Tables 1-2.

Table 1. Indicators of quality of educational services of top 10 digital universities in Russia in 2017 and 2018

\begin{tabular}{|c|c|c|c|c|c|c|}
\hline \multicolumn{2}{|c|}{ University } & \multirow{2}{*}{$\begin{array}{c}\text { E1: } \\
\begin{array}{c}\text { Educational } \\
\text { activities }\end{array} \\
64.88\end{array}$} & \multirow{2}{*}{$\begin{array}{c}\text { E2: } \\
\text { Research } \\
\text { activities } \\
533.49 \\
\end{array}$} & \multirow{2}{*}{$\begin{array}{c}\text { E3: } \\
\begin{array}{c}\text { Internationa } \\
\text { l activities }\end{array} \\
4.19\end{array}$} & \multirow{2}{*}{$\begin{array}{c}\text { E4: } \\
\begin{array}{c}\text { Financial } \\
\text { and }\end{array} \\
\text { economic } \\
\text { activities }\end{array}$} & \multirow{2}{*}{$\begin{array}{c}\begin{array}{c}\text { E5: Wages } \\
\text { of academic } \\
\text { staff }\end{array} \\
206.2\end{array}$} \\
\hline & 2018 & & & & & \\
\hline MIRSU & 2017 & 63.85 & 466.39 & 3.35 & 3265.52 & 203.58 \\
\hline \multirow{2}{*}{ MFLU } & 2018 & 56.95 & 115.53 & 3.60 & 2389.33 & 205.02 \\
\hline & 2017 & 54.81 & 118.39 & 3.25 & 1825.39 & 160.67 \\
\hline \multirow{2}{*}{ RSUH } & 2018 & 61.51 & 63.97 & 1.41 & 3790.96 & 204.99 \\
\hline & 2017 & 62.14 & 132.01 & 1.28 & 3751.17 & 91.47 \\
\hline \multirow{2}{*}{$\begin{array}{c}\text { NR } \\
\text { MSUCE }\end{array}$} & 2018 & 61.01 & 845.6 & 3.35 & 7573 & 259.66 \\
\hline & 2017 & 61.63 & 597.37 & 3.24 & 5368.64 & 159.39 \\
\hline \multirow{2}{*}{ FU } & 2018 & 74.9 & 228.61 & 7.6 & 5009.18 & 187.02 \\
\hline & 2017 & 76.9 & 205.55 & 7.99 & 4401.02 & 166.11 \\
\hline \multirow{2}{*}{ MISiS } & 2018 & 76.84 & 2543.2 & 24.29 & 8580.07 & 192.48 \\
\hline & 2017 & 77.21 & 2324.65 & 22.63 & 7799.35 & 163.13 \\
\hline \multirow{2}{*}{ MCPU } & 2018 & 73.6 & 741.14 & 4.12 & 3785.79 & 188.04 \\
\hline & 2017 & 72.1 & 691.08 & 4.08 & 3509.06 & 158.44 \\
\hline \multirow{2}{*}{ MSUCE } & 2018 & 67.36 & 769.12 & 5.32 & 4542.5 & 207.61 \\
\hline & 2017 & 66.96 & 674.11 & 5.19 & 4861.79 & 167.89 \\
\hline \multirow{2}{*}{ RUT } & 2018 & 57.45 & 511.51 & 3.67 & 3682.79 & 211.61 \\
\hline & 2017 & 58.23 & 432.82 & 3.27 & 3777.39 & 171.09 \\
\hline \multirow{2}{*}{ MSUGC } & 2018 & 62.57 & 178.63 & 4.91 & 3527.76 & 124,28 \\
\hline & 2017 & 63.53 & 238.23 & 4.97 & 2202.02 & 74.38 \\
\hline
\end{tabular}

Source: compiled by the authors based on Ministry of Education and Science of the Russian Federation (2019b). 
Table 2. Indicators of results of implementing the marketing practices of top 10 digital universities in Russia in 2017 and 2018

\begin{tabular}{|c|c|c|c|c|c|c|}
\hline \multicolumn{2}{|c|}{ University } & $\begin{array}{l}\text { Revenues of } \\
\text { universities } \\
\text { from all } \\
\text { sources, RUB } \\
\text { thousand }\end{array}$ & $\begin{array}{c}\text { Share of } \\
\text { full-time } \\
\text { employees } \\
\text { of } \\
\text { academic } \\
\text { staff in the } \\
\text { total } \\
\text { number of } \\
\text { academic } \\
\text { staff, \% } \\
\end{array}$ & $\begin{array}{c}\text { Total } \\
\text { number of } \\
\text { students, } \\
\text { people }\end{array}$ & $\begin{array}{l}\text { Share of } \\
\text { university's } \\
\text { revenues } \\
\text { from non- } \\
\text { budget } \\
\text { sources, \% }\end{array}$ & $\begin{array}{c}\text { Share of } \\
\text { foreign } \\
\text { students, \% }\end{array}$ \\
\hline \multirow{2}{*}{ MRSU } & 2018 & 2533330.90 & 89.79 & 10769 & 19.32 & 4.19 \\
\hline & 2017 & 2351825.40 & 92.28 & 10906 & 16.20 & 3.35 \\
\hline \multirow{2}{*}{ MFLU } & 2018 & 96170.50 & 67.35 & 980 & 100.00 & 3.63 \\
\hline & 2017 & 79404.50 & 68.63 & 980 & 100.00 & 3.94 \\
\hline \multirow{2}{*}{ RSUH } & 2018 & 112591.50 & 69.70 & 980 & 100.00 & 4.08 \\
\hline & 2017 & 113660.60 & 89.66 & 923 & 100.00 & 3.96 \\
\hline \multirow{2}{*}{$\begin{array}{c}\text { NR } \\
\text { MSUCE }\end{array}$} & 2018 & 100342.30 & 73.91 & 445 & 31.96 & 1.09 \\
\hline & 2017 & 69792.30 & 83.33 & 2543 & 47.55 & 2.30 \\
\hline \multirow{2}{*}{$\mathbf{F U}$} & 2018 & 5801133.60 & 76.27 & 18485 & 44.67 & 7.60 \\
\hline & 2017 & 5238318.30 & 77.31 & 18798 & 47.56 & 7.98 \\
\hline \multirow{2}{*}{ MISiS } & 2018 & 5706607.10 & 75.43 & 7757 & 35.57 & 24.28 \\
\hline & 2017 & 6392736.20 & 76.07 & 8411 & 32.73 & 22.62 \\
\hline \multirow{2}{*}{ MCPU } & 2018 & 3386385.30 & 85.49 & 12486 & 29.78 & 4.11 \\
\hline & 2017 & 3337993.40 & 90.69 & 11514 & 23.11 & 4.08 \\
\hline \multirow{2}{*}{ MSUCE } & 2018 & 3524982.20 & 83.96 & 11205 & 44.50 & 5.32 \\
\hline & 2017 & 3533789.70 & 83.51 & 10191 & 46.44 & 5.19 \\
\hline \multirow{2}{*}{ RUT } & 2018 & 5653815.90 & 80.86 & 31714 & 70.67 & 3.67 \\
\hline & 2017 & 5456816.30 & 82.84 & 31961 & 68.34 & 3.24 \\
\hline \multirow{2}{*}{ MSUGC } & 2018 & 814029.70 & 83.38 & 3969 & 35.41 & 4.91 \\
\hline & 2017 & 636602.90 & 93.57 & 3625 & 33.74 & 4.97 \\
\hline
\end{tabular}

The obtained results of processing of the initial data from Tables 1 and 2 with the help of horizontal analysis, which reflect the growth of indicators of quality and results of marketing practices of top 10 digital universities in Russia in 2018, as compared 2017 , and direct average of growth in view of the indicators and in view of universities, are given in Table 3.

As shown in Table 3, the highest growth of direct average of the indicators of quality of the provided educational services among top 10 digital universities in Russia in 2018, as compared to 2017, took place in NR MSUCE (1.30) and MSUGC (1.20); the lowest - in MCPU (1.07) and MSUCE (1.07). The highest growth (increase) o direct average of the indicators of results of implementation of marketing practices has been achieved in MRSU (1.10) and MCPU (1.07); the lowest (reduction) - in FU (0.99), MISiS (0.99), RSUH (0.97), and NR MSUCE (0.73). 
Table 3. Growth (horizontal analysis) of the indicators of quality and results of marketing practices of top 10 digital universities in Russia in 2018.

\begin{tabular}{|c|c|c|c|c|c|c|}
\hline \multirow{3}{*}{ University } & \multicolumn{6}{|c|}{ Indicators of quality } \\
\hline & $\begin{array}{c}\text { E1: } \\
\text { Educational } \\
\text { activities }\end{array}$ & \begin{tabular}{c|c} 
E2: & \\
Research & $\mathbf{I}$ \\
activities &
\end{tabular} & $\begin{array}{c}\text { E3: } \\
\text { International } \\
\text { activities }\end{array}$ & $\begin{array}{c}\text { E4: } \\
\text { Financial } \\
\text { and } \\
\text { economic } \\
\text { activities }\end{array}$ & $\begin{array}{c}\text { E5: Wages } \\
\text { of academic } \\
\text { staff }\end{array}$ & \multirow[t]{2}{*}{$\begin{array}{c}\text { On } \\
\text { average }\end{array}$} \\
\hline & $\mathbf{x}_{1}$ & $\mathbf{x} 2$ & $\mathbf{x}_{3}$ & $\mathbf{x} 4$ & $\mathbf{x} 5$ & \\
\hline MRSU & 1.02 & 1.14 & 1.25 & 1.18 & 1.01 & 1.12 \\
\hline MFLU & 1.04 & 0.98 & 1.11 & 1.31 & 1.28 & 1.14 \\
\hline RSUH & 0.99 & 0.48 & 1.10 & 1.01 & 2.24 & 1.17 \\
\hline $\begin{array}{c}\text { NR } \\
\text { MSUCE }\end{array}$ & 0.99 & 1.42 & 1.03 & 1.41 & 1.63 & 1.30 \\
\hline FU & 0.97 & 1.11 & 0.95 & 1.14 & 1.13 & 1.06 \\
\hline MISiS & 1.00 & 1.09 & 1.07 & 1.10 & 1.18 & 1.09 \\
\hline MCPU & 1.02 & 1.07 & 1.01 & 1.08 & 1.19 & 1.07 \\
\hline MSUCE & 1.01 & 1.14 & 1.03 & 0.93 & 1.24 & 1.07 \\
\hline RUT & 0.99 & 1.18 & 1.12 & 0.97 & 1.24 & 1.10 \\
\hline MSUGC & 0.98 & 0.75 & 0.99 & 1.60 & 1.67 & 1.20 \\
\hline $\begin{array}{c}\text { On } \\
\text { average }\end{array}$ & 1.00 & 1.04 & 1.07 & 1.17 & 1.38 & 1.13 \\
\hline \multirow{3}{*}{ University } & \multicolumn{6}{|c|}{ Marketing results } \\
\hline & $\begin{array}{c}\text { University's } \\
\text { revenues } \\
\text { from all } \\
\text { sources, RUB } \\
\text { thousand }\end{array}$ & $\begin{array}{c}\text { Share of full- } \\
\text { time } \\
\text { academic } \\
\text { staff in the } \\
\text { total number } \\
\text { of academic } \\
\text { staff, \% }\end{array}$ & \begin{tabular}{|c|c|} 
Total \\
number of \\
students, \\
people
\end{tabular} & $\begin{array}{c}\text { Share of } \\
\text { university's } \\
\text { revenues } \\
\text { from non- } \\
\text { budget } \\
\text { sources, \% }\end{array}$ & $\begin{array}{c}\text { Share of } \\
\text { foreign } \\
\text { students, } \\
\%\end{array}$ & \multirow[t]{2}{*}{$\begin{array}{c}\text { On } \\
\text { average }\end{array}$} \\
\hline & $\mathrm{y}_{1}$ & $\mathrm{y}_{2}$ & $\mathrm{y}_{3}$ & $\mathrm{y}_{4}$ & $\mathrm{y}_{5}$ & \\
\hline MRSU & 1.08 & 0.97 & 0.99 & 1.19 & 1.25 & 1.10 \\
\hline MFLU & 1.21 & 0.98 & 1.00 & 1.00 & 0.92 & 1.02 \\
\hline RSUH & 0.99 & 0.78 & 1.06 & 1.00 & 1.03 & 0.97 \\
\hline $\begin{array}{c}\text { NR } \\
\text { MSUCE }\end{array}$ & 1.44 & 0.89 & 0.17 & 0.67 & 0.47 & 0.73 \\
\hline $\mathbf{F U}$ & 1.11 & 0.99 & 0.98 & 0.94 & 0.95 & 0.99 \\
\hline MISiS & 0.89 & 0.99 & 0.92 & 1.09 & 1.07 & 0.99 \\
\hline MCPU & 1.01 & 0.94 & 1.08 & 1.29 & 1.01 & 1.07 \\
\hline MSUCE & 1.00 & 1.01 & 1.10 & 0.96 & 1.03 & 1.02 \\
\hline RUT & 1.04 & 0.98 & 0.99 & 1.03 & 1.13 & 1.03 \\
\hline MSUGC & 1.28 & 0.89 & 1.09 & 1.05 & 0.99 & 1.06 \\
\hline $\begin{array}{c}\text { On } \\
\text { average }\end{array}$ & 1.10 & 0.94 & 0.94 & 1.02 & 0.99 & 1.00 \\
\hline
\end{tabular}

Source: calculated by the authors 
Average growth of quality for the indicator of educational activities is zero (1.00), but growth for the indicator of research activities constituted 1.04, for the indicator of international activities - 1.07, for the indicator of financial and economic activities - 1.17, and for the indicator of wages of academic staff -1.38 . Average growth of the results of implementing the marketing practices as to university's revenues from all sources constituted 1.10 , as to the share of full-time academic staff in the total number of academic staff - 0.94 (decrease), as to total number of students -0.94 (decrease), as to the share of university's revenues from nonbudget sources -1.02 , as to share of foreign students -0.99 (decrease).

Results of the performed regression analysis in view of the distinguished results of implementation of the marketing practices of top 10 digital universities in Russia in 2018 are shown in Figures 4-8.

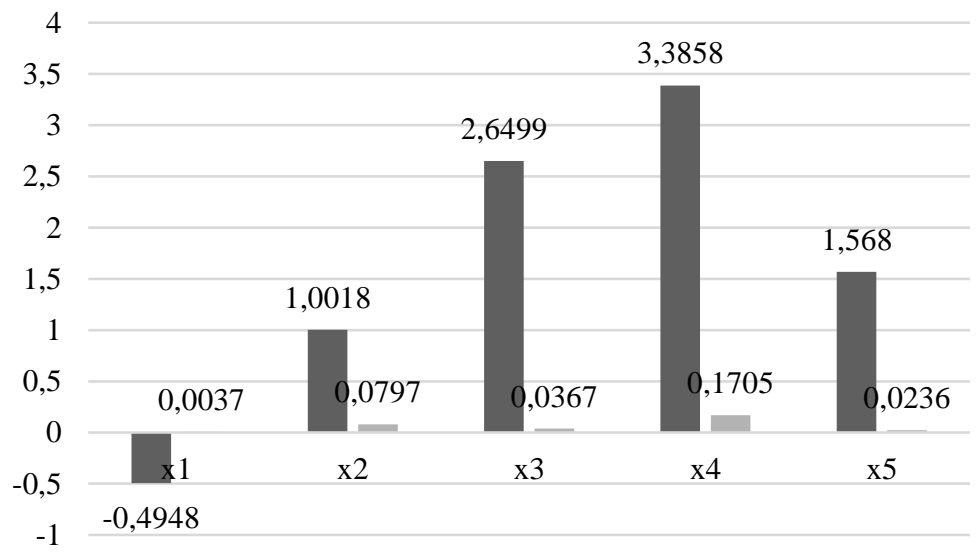

Figure 4. Characteristics of dependence of university's revenues from all sources $\left(\mathrm{y}_{1}\right)$ on the indicators of quality

Source: calculated by the authors

According to the data from Figure 4, growth of direct average of the indicator of educational activities by 1 leads to reduction of average growth of revenues from all sources of top 10 digital universities in Russia in 2018, as compared to 2017 , by 0.4948 $\left(\mathrm{R}^{2}=0.0037\right)$; growth of direct average of the indicator of research activities by 0.1 . leads to its growth by $1.0018\left(\mathrm{R}^{2}=0.0797\right)$; growth of direct average of the indicator of international activities by 0.1 leads to its growth by 2.6499 $\left(\mathrm{R}^{2}=0.0367\right)$; growth of direct average of the indicator of finance and economy by 0.1 leads to its growth by $3.3858\left(\mathrm{R}^{2}=0.1705\right)$; growth of direct average of the indicator of wages of academic staff by 0.1 leads to its growth by $1.568\left(\mathrm{R}^{2}=0.0236\right)$. That's why revenues from all sources of top 10 digital universities in Russia in 2018 are determined by the financial \& economic, international, and research activities, as well as wages of the academic staff.

According to the data from Figure 5, growth of direct average of the indicator of educational activities by 1 leads to growth of the share of full-time academic staff in the total number of academic staff in top 10 digital universities in Russia in 2018, as compared to 2017 , by 0.159 (reverse $\mathrm{R}^{2}=-$ 0.0631 ); growth of direct average of the indicator of research activities by 0.1 leads to its growth by $0.1758\left(R^{2}=0.4051\right)$; growth of direct average of the indicator of international activities by 0.1 leads to its decrease by 
$0.6265\left(\mathrm{R}^{2}=0.0389\right)$; growth of direct average of the indicator of finance and economy by 0.1 leads to its decrease by 0.1812 $\left(\mathrm{R}^{2}=0.0806\right)$; growth of direct average of the indicator of wages of academic staff by 0.1 leads to its decrease by $0.2689\left(\mathrm{R}^{2}=0.1147\right)$.
That's why the share of full-time academic staff in the total number of academic staff of top 10 digital universities in Russia in 2018 is determined by their educational and research activities.

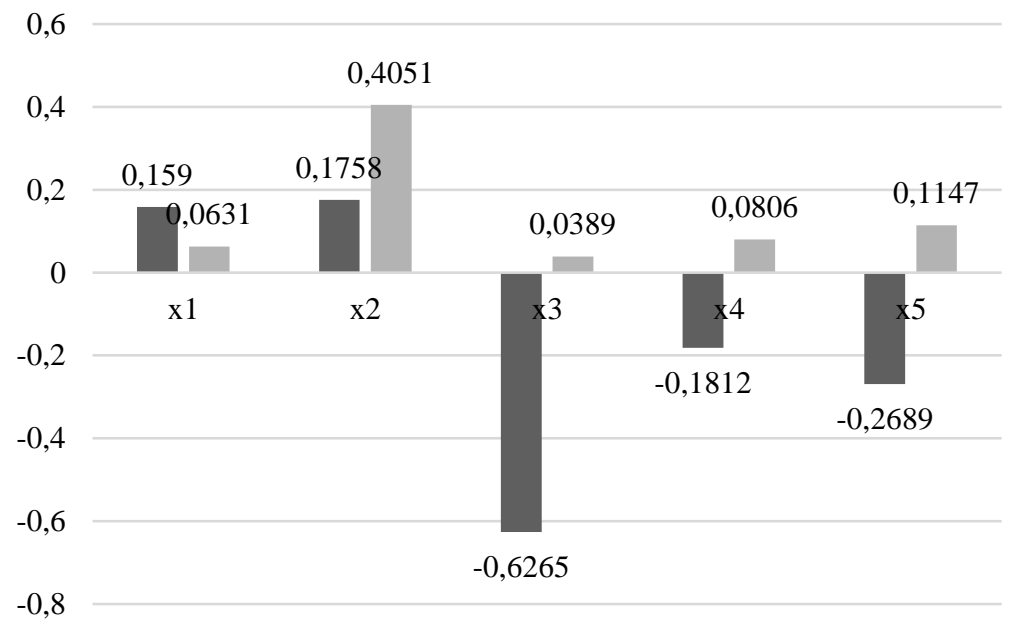

Figure 5. Characteristics of dependence of the share of full-time academic staff in the total number of academic staff $\left(\mathrm{y}_{2}\right)$ on the indicators of quality Source: calculated by the authors

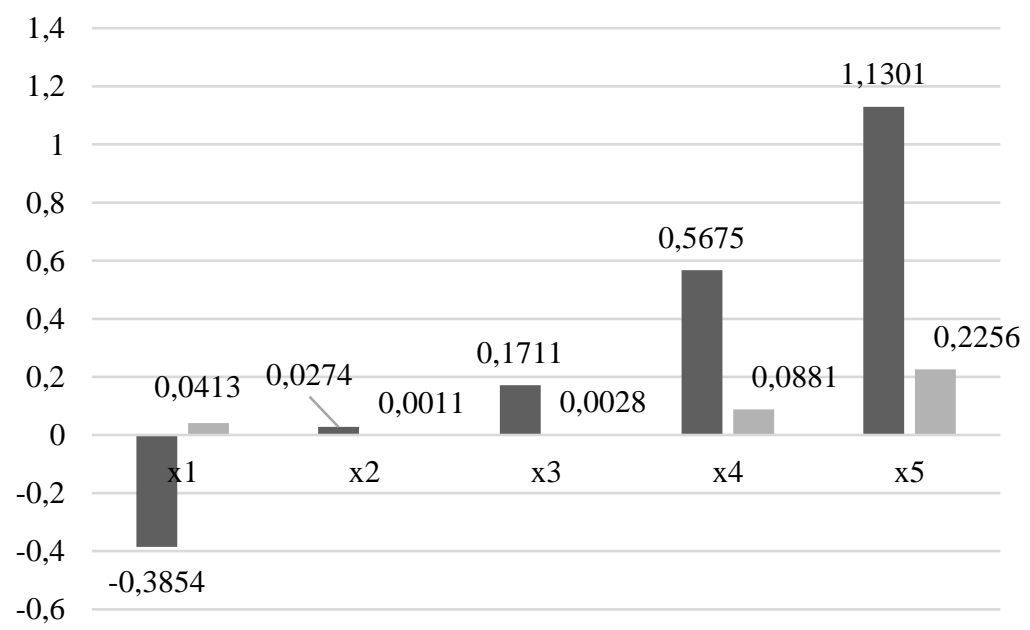

Figure 6. Characteristics of dependence of the total number of students $\left(\mathrm{y}_{3}\right)$ on the indicators of quality

Source: calculated by the authors 
According to data from Figure 6, growth of direct average of the indicator of educational activities by 1 leads to decrease of average growth of revenues of top 10 digital universities in Russia in 2018, as compared to 2017 , by 0.3854 (reverse $R^{2}=0.0413$ ); growth of direct average of the indicator of research activities by 0.1 leads to its growth by 0.0274 $\left(\mathrm{R}^{2}=0.0011\right)$; growth of direct average of the indicator of international activities by 0.1 leads to its growth by $0.1711\left(\mathrm{R}^{2}=0.0028\right)$; growth of direct average of the indicator of finance and economy by 0.1 leads to its growth by $0.5675\left(\mathrm{R}^{2}=0.0881\right)$; growth of direct average of the indicator of wages of academic staff by 0.1 leads to its growth by $1.1301\left(\mathrm{R}^{2}=0.2256\right)$. That's why total number of students of top 10 digital universities in Russia in 2018 was determined by the financial \& economic, international, and research activities, as well as wages of academic staff.

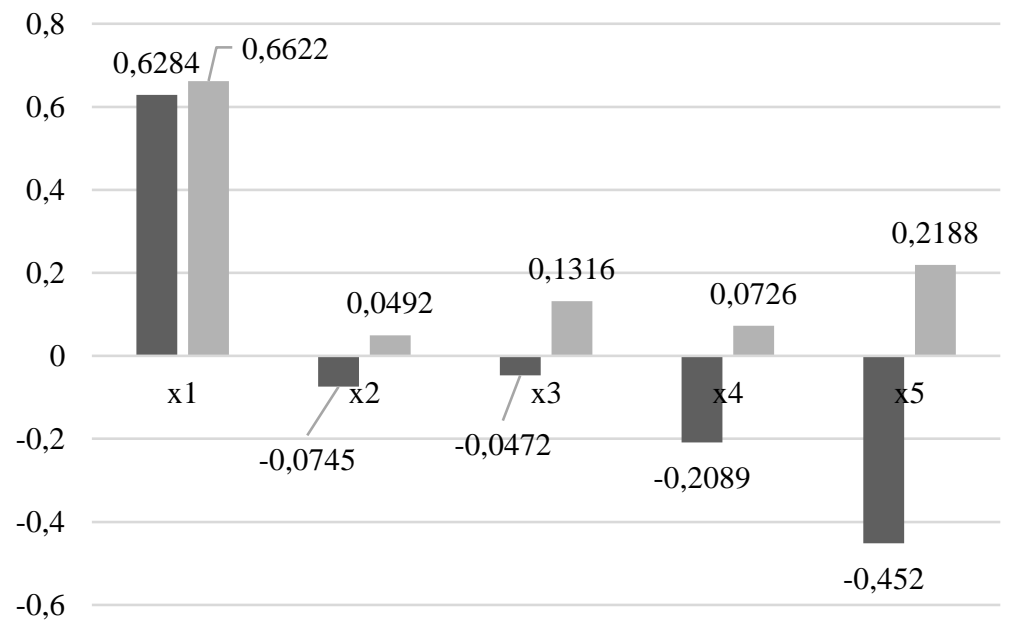

Figure 7. Characteristics of dependence of the share of university's revenues from non-budget sources $\left(\mathrm{y}_{4}\right)$ on the indicators of quality

Source: calculated by the authors

According to the data from Figure 7, growth of direct average of the indicator of educational activities by 1 leads to increase of average growth of the share of revenues from non-budget sources of top 10 digital universities in Russia in 2018, as compared to 2017 , by $0.6284\left(\mathrm{R}^{2}=0.6622\right)$; growth of direct average of the indicator of research activities by 0.1 leads to its decrease by $0.0745\left(\mathrm{R}^{2}=0.0492\right)$; growth of direct average of the indicator of international activities by 0.1 leads to its decrease by 0.0472 $\left(\mathrm{R}^{2}=0.1316\right)$; growth of direct average of the indicator of finance and economy by 0.1 leads to its decrease by $0.2089\left(R^{2}=0.0726\right)$; growth of direct average of the indicator of wages of academic staff by 0.1 leads to its decrease by $0.452\left(\mathrm{R}^{2}=0.2188\right)$. That's why the share of revenues from non-budget sources of top 10 digital universities in Russia in 2018 was determined by their educational activities.

According to the data from Figure 8, growth of direct average of the indicator of educational activities by 1 leads to increase of average growth of the share of foreign students of top 10 digital universities in Russia in 2018, as compared to 2017, by 0.0976 (reverse $R^{2}=0.0492$ ); growth of direct average of the indicator of research activities by 0.1 leads to its decrease by 0.1817 $\left(\mathrm{R}^{2}=0.8958\right)$; growth of direct average of the indicator of international activities by 0.1 
leads to its decrease by $0.1069\left(\mathrm{R}^{2}=0.0204\right)$; growth of direct average of the indicator of finance and economy by 0.1 leads to its decrease by $0.1598\left(R^{2}=0.1297\right)$; growth of direct average of the indicator of wages of academic staff by 0.1 leads to its decrease by $0.18\left(\mathrm{R}^{2}=0.1063\right)$. That's why the share of foreign students of top 10 digital universities in Russia in 2018 was determined by educational activities.

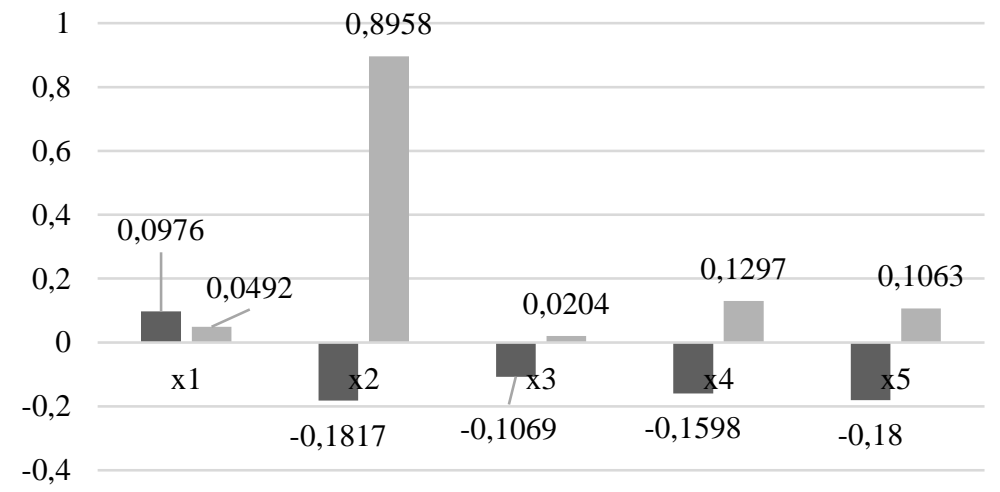

Figure 8. Characteristics of dependence of the share of foreign students $\left(\mathrm{y}_{5}\right)$ on the indicators of quality

Source: calculated by the authors

Thus, we determined direct connection (positive value of direct average of all estimate coefficients $b$, which constituted 0.3279 ) of the indicators of quality of educational services, provided by digital universities, and efficiency of their marketing practices (0.1484), based on which hypothesis $\mathrm{H}_{1}$ is deemed proved.

\subsection{Recommendations for} institutionalization of successful marketing practices of digital universities based on quality management in modern Russia

We develop and recommend the algorithm of institutionalization of successful marketing practices of digital universities based on quality management (Figure 9).

As shown in Figure 9, the initial point of the offered algorithm is preliminary preparatory stage, connected to stimulation of the marketing activity of digital universities based on quality management. For this, it is recommended to adopt the criterion "marketing activity" in the methodology of evaluating effectiveness of universities and to set requirements to manifestation of high marketing activity as a condition of financing the activities of regional flagship universities of Russia.

It is also offered to adopt a precise set of characteristics of quality of educational services of digital universities (e.g., ratio of the number of students and a set of specialties) and their separate statistical accounting. For state digital universities there should be additional stimulating payments for high quality of the provided educational services. At this stage, the subject of management of institutionalization of successful marketing practices of digital universities is the state, and at other stages digital universities. 
Preliminary preparatory stage: Stimulating marketing activities of digital universities based on quality management

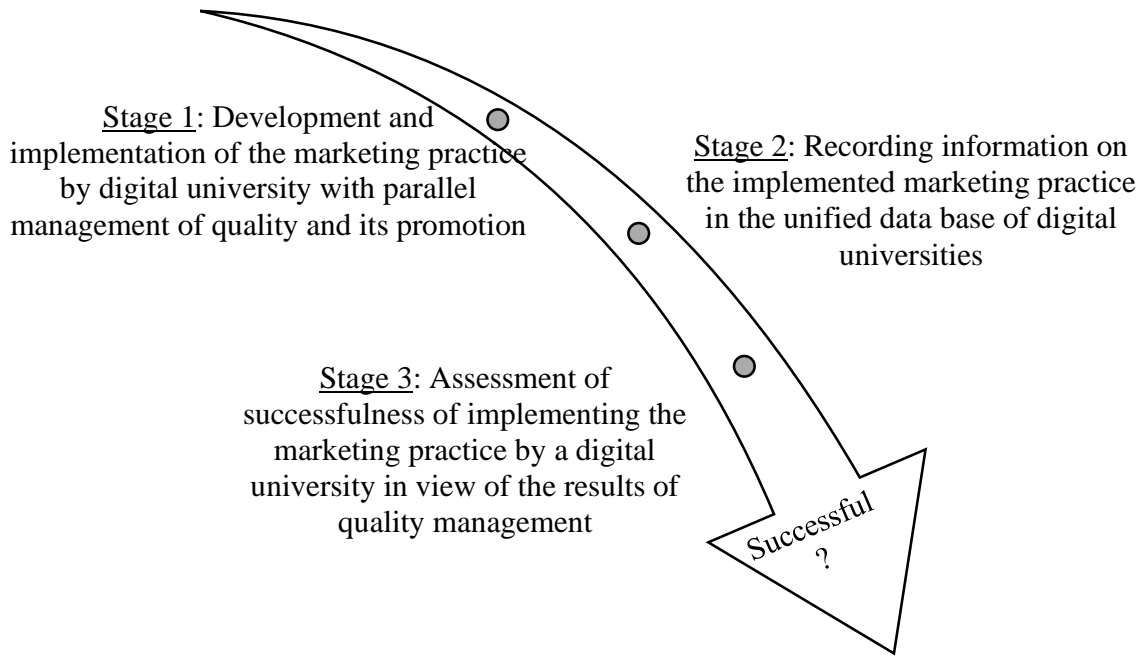

Stage 4: Assessment of reasons of low success or Exchange of successful experience with emphasis on quality

Figure 9. Algorithm of institutionalization of successful marketing practices of digital universities in modern Russia

Source: compiled by the authors

The first stage of the algorithm is development and implementation of the marketing practice by digital university with parallel management of quality (determining weak characteristics of quality and their improvement) and its promotion (emphasis on guarantee of high quality with advertising and PR of digital university and its services). We distinguish the following types of target marketing practices of digital universities:

- Promotion of digital universities (applied leading digital technologies, provided digital form of provision of educational services, and implemented educational programs for training of digital personnel);

- Attracting and keeping personnel (personnel marketing);

- Attraction of consumers (advertising and PR);
- Attraction of investments (marketing of investments);

- Entering new markets (global marketing).

The second stage of the algorithm is adoption of information on the implemented marketing practice in the unified data base of digital universities (organized with the help of blockchain technologies). The third stage of the algorithm is assessment of successfulness of implementing the marketing practice by the digital university in view of the results of quality management (internal audit and state monitoring of quality could be conducted). For the second and third stages we developed a special form (Table 4) according to the parameters of digital education, which are taken into account by the World Bank specialists (World Bank, 2019). 
Table 4. Form for recording information on the implemented marketing practice of a digital university and assessment of its successfulness

\begin{tabular}{|c|c|c|c|c|c|}
\hline \multirow{2}{*}{$\begin{array}{l}\text { Indicators of } \\
\text { successfulness } \\
\text { of application } \\
\text { of the practice }\end{array}$} & \multicolumn{5}{|c|}{ Types of target marketing practices of digital universities } \\
\hline & $\begin{array}{c}\text { Promotion of } \\
\text { digital } \\
\text { universities }\end{array}$ & $\begin{array}{c}\text { Attracting and } \\
\text { keeping personnel }\end{array}$ & $\begin{array}{l}\text { Attraction of } \\
\text { consumers }\end{array}$ & $\begin{array}{c}\text { Attraction of } \\
\text { investments }\end{array}$ & $\begin{array}{c}\text { Entering new } \\
\text { markets }\end{array}$ \\
\hline \multirow{3}{*}{$\begin{array}{c}\text { Indicators of } \\
\text { profits }\end{array}$} & $\begin{array}{l}\text { growth of } \\
\text { market's volume }\end{array}$ & $\begin{array}{c}\text { number of attracted } \\
\text { personnel }\end{array}$ & $\begin{array}{c}\text { growth of sales } \\
\text { volume }\end{array}$ & $\begin{array}{c}\text { volume of } \\
\text { attracted } \\
\text { investments }\end{array}$ & $\begin{array}{l}\text { number of new } \\
\text { foreign students }\end{array}$ \\
\hline & $\begin{array}{c}\text { growth of } \\
\text { volume of sales }\end{array}$ & $\begin{array}{l}\text { growth of labor } \\
\text { efficiency }\end{array}$ & $\begin{array}{l}\text { growth of } \\
\text { number of } \\
\text { students }\end{array}$ & $\begin{array}{c}\text { number of new } \\
\text { investors }\end{array}$ & $\begin{array}{l}\text { volume of } \\
\text { provided } \\
\text { additional } \\
\text { services } \\
\end{array}$ \\
\hline & - & $\begin{array}{c}\text { growth of production } \\
\text { capacities }\end{array}$ & - & - & - \\
\hline \multirow{3}{*}{$\begin{array}{l}\text { Indicators of } \\
\text { expenditures }\end{array}$} & \multicolumn{5}{|c|}{ executed marketing budget } \\
\hline & \multicolumn{5}{|c|}{ number of used personnel } \\
\hline & \multicolumn{5}{|c|}{ additionally used resources (if available) } \\
\hline
\end{tabular}

Source: compiled by the authors

As shown in Table 4, the offered form reflects the logic of recording the information on the marketing practice of a digital university and suggests the indicators for evaluating its successfulness. The fourth stage of the algorithm is evaluation of the reasons of low successfulness or exchange of successful experience with emphasis on quality. For this, it is offered to organized conferences, forums, and other events with participation of digital universities.

\section{Conclusion}

Thus, digital universities and their marketing activities are new phenomena for the modern Russian economy. Low marketing activity and insufficient attention to the issues of managing the quality of provided educational services slow down the development of digital universities, causing low demand for the provided innovative educational services with the usage of the leading digital technologies in the educational process, with application of the digital form of provision of educational services, and connected educational programs for training of digital personnel. The offered recommendations will allow increasing the quality and marketing activity of digital universities in modern Russia and ensuring institutionalization of their successful marketing practices, thus stimulating the increase of efficiency of their marketing activities.

\section{References:}

Ahern, M. F. (2018). Online Power Education: Keeping Pace with the Demand for High-Quality, Flexible Education. IEEE Power and Energy Magazine, 16(5), 8438377, 82-86.

Akşit, M. (2018). The Role of Computer Science and Software Technology in Organizing Universities for Industry 4.0 and beyond. Proceedings of the 2018 Federated Conference on Computer Science and Information Systems, FedCSIS 2018, 8511200, 5-11.

Blieck, Y., Ooghe, I., Zhu, C., Depryck, K., Pynoo, B., \& Van Laer, H. (2019). Consensus among stakeholders about success factors and indicators for quality of online and blended learning in adult education: a Delphi study. Studies in Continuing Education, 41(1), 36-60. 
Digital economy of the Russian Federation 2024, Personnel for the digital economy: "Personnel and education" as directions of the program "Digital economy of the Russian Federation" (2019). Retrieved from: https://data-economy.ru/education

Du, J., Li, F., \& Xiao Wang, X. (2018). Research and construction method of service quality evaluation model based on customer perception in online education field. 13th International Conference on Computer Science and Education, ICCSE 2018, 8468731, 462-465.

Esfijani, A. (2018). Measuring Quality in Online Education: A Meta-synthesis. American Journal of Distance Education, 32(1), 57-73.

Fund of public opinion research, Remote education in Russia: results of a sociological survey (2019). Retrieved from: https://fom.ru/Nauka-i-obrazovanie/11118

Gregory-Smith, D., Manika, D., Wells, V. K., \& Veitch, T. (2018). Examining the effect of an environmental social marketing intervention among university employees. Studies in Higher Education, 43(11), 2104-2120.

$\mathrm{Hu}$, Y. (2013). Study on quality improvement of remote education with alternate-oriented tutorship. Lecture Notes in Electrical Engineering, 208 LNEE, 343-347.

Kazimirov, A. N. (2018). Education at University and Industry 4.0. Proceedings - 2018 Global Smart Industry Conference, GloSIC 2018, 8570076.

Ministry of Education and Science of the Russian Federation, 51flagship universities of Russia (2019a). Retrieved from: https://obrmos.ru/go/go_vys/Articles/go_vys_50op_vyz.html

Ministry of Education and Science of the Russian Federation, Informatio and analytical materuals as a result of monitoring of effectiveness of activities of educational organizations of higher education (2019b). Retrieved from: http://indicators.miccedu.ru/monitoring/?m=vpo

Mishra, B. B., \& Mishra, S. (2018). Quality Improvements in Online Education System by Using Data Mining Techniques. Proceedings - 2nd International Conference on Data Science and Business Analytics, ICDSBA 2018, 8588974, 532-536.

Osman, A., Saputra, R., \& Luis, M. (2018). Exploring mediating role of institutional image through a complete Structural Equation Modeling (SEM): A perspectve of higher education. International Journal for Quality Research, 12(2), 517-536.

Pedro, E., Mendes, L., \& Lourenço, L. (2018). Perceived service quality and students' satisfaction in higher education: The influence of teaching methods. International Journal for Quality Research, 12(1), 165-192.

Peruta, A., \& Shields, A.B. (2018). Marketing your university on social media: a content analysis of Facebook post types and formats. Journal of Marketing for Higher Education, 28(2), 175191.

Petrenko, E., Pritvorova, T., \& Dzhazykbaeva, B. (2018). Sustainable developmett processes: Service sector in post-industrial economy. Journal of Security and Sustainability Issues, 7(4), 781-791. doi: https://doi.org/10.9770/jssi.2018.7.4(14).

Popkova (2019). Preconditions of formation and development of industry 4.0 in the conditions of knowledge economy. Studies in Systems, Decision and Control, 169(1), 65-7

Popkova, E., Vovchenko, N. \& Yepifanova, T. (2017a). Advanced tools and performance criteria of modern media education. Mediaobrazovanie-media education, 1(1), 26-37.

Popkova, E. G. \& Sergi, B. S. (Eds.) (2019). Digital Economy: Complexity and Variety vs. Rationality. Springer International Publishing. 
Popkova, E. G. (2019). Preconditions of formation and development of industry 4.0 in the conditions of knowledge economy. Studies in Systems, Decision and Control, 169(1), 65-7

Popkova, E. G., Vovchenko, N. G., \& French, J. (2017b). Media Education in the Globalizing World: New Criteria and Priorities. Mediaobrazovanie-media education, 2(1), 43-50.

Popkova, E. G., Vovchenko, N. G., \& French, J. (2017c). Strategic Role of Media Education in the Conditions of Development of Information Economy. Mediaobrazovanie-media education, 3(1), 54-60.

Saud, M. S., Rameli, M. R. M., Kosnin, A. M., Yahaya, N., Kamin, Y., (...), \& Omar, M. (2018). Readiness in implementing teacher training programmes based on industrial revolution 4.0: Evidence from Malaysian public universities. Journal of Engineering Science and Technology, 13(Special Issue on ICITE 2018), 42-48.

Schuettler, T., Maman, S., \& Girwidz, R. (2019). Teaching remote sensing techniques with highquality, low-cost sensors [Education]. IEEE Geoscience and Remote Sensing Magazine, 7(2),8738024, 185-190.

Sekerin, V. D., Gorokhova, A. E., Dudin, M. N., Danko, T. P., \& Nikolaykin, N. I. (2018). Applying interactive marketing methods to improve the quality of university educational services. Quality - Access to Success, 19(163), 37-42.

Sharok, V. (2018). Role of socio-psychological factors of satisfaction with education in the quality assessment of university. International Journal for Quality Research, 12(2), 281-296.

Sibirskaya, E., Popkova, E., \& Oveshnikova, L. (2019). Remote education vs traditional education based on effectiveness at the micro level and its connection to the level of development of macro-economic systems. International journal of educational management, 33(3, special issue),.533-543.

Sozinova, A. A. (2019). Causal connections of formation of industry 4.0 from the positions of the global economy. Studies in Systems, Decision and Control, 169(1), 131-143.

Stracke, C. M., \& Tan, E. (2018). The quality of open online education and learning: Towards a quality reference framework for moocs. Proceedings of International Conference of the Learning Sciences, ICLS, 2(2018-June), 1029-1032.

University NTI 20.35, About the university (2019). Retrieved from: https://2035.university

Vučijak, B., Bošnjak Pašić, M., Šaković Jovanović, J., Idrizi, A., Xhevdet, T., (...), \& Gojković, R. (2018). Practices in entrepreneurship education in South East Europe and Russia. International Journal for Quality Research, 12(3), 741-756.

Vuzopedia. Rating of digital universities of Russia - 2019 (2019). Retrieved from: http://vuzopedia.ru/vuz?f=distantsionnye

World Bank, Competing in the digital age: Policy implications for the Russian Federation: Digital education (2019). Retrieved from: http://documents.worldbank.org/ curated/en/848071539115489168/pdf/AUS0000158-RUSSIAN-WP-REVISED-P160805-

PUBLIC-Disclosed-10-15-2018.pdf 
Irina P. Devetyarova

Vyatka State University, Kirov,

Russian Federation

ip_devetyarova@vyatsu.ru
Oksana S. Agalakova

Vyatka State University, Kirov,

Russian Federation

os_agalakova@vyatsu.ru
Larisa S. Cheglakova

Vyatka State University, Kirov,

Russian Federation

1s_cheglakova@vyatsu.ru

Yulia A. Kolesova

Vyatka State University,

Kirov,

Russian Federation

usr11010@vyatsu.ru 
QUALIry International Journal for Quality Research 